\title{
Membangun Kepercayaan Konsumen untuk Meningkatkan Intensi Pembelian
}

\author{
Ida Bagus Nyoman Udayana*, Aria Pramana \\ Fakultas Ekonomi, Universitas Sarjanawiyata Tamansiswa, Indonesia \\ *ibn.udayana@yahoo.co.id
}

\begin{abstract}
The aim of this research is to examine how to build consumer trust to increase purchase intention in the case study of the SoWellShop online store through testing the effect of ability, benevolence of business and integrity on customer trust and testing the effect of customer trust on purchase intention. The sampling method is non-probability, and the sampling technique uses purposive sampling. Data collected through questionnaires given to 100 respondents. The data analysis uses regression.. The results show that: 1) ability, benevolence of business, and integrity have a significant and positive effect on customer trust, 2) the customer trust has a significant and positive effect on the purchase intention variable.
\end{abstract}

Keywords: Ability, Benevolence of Business, Customer Trust, Integrity, Purchase Intention

\section{PENDAHULUAN}

Perkembangan teknologi membuat masyarakat semakin mudah dalam melakukan kegiatan setiap harinya. Terutama dalam memperoleh berbagai informasi baik berita, saham, informasi, maupun jual beli. Semakin bertambahnya pengguna internet di Indonesia, merupakan pemicu dalam berkembangnya jual beli online di Indonesia. Dengan masuknya jual beli online di Indonesia, maka akan meringankan kegiatan jual beli konsumen dan dapat memperluas jaringan pasar penjual. Dengan demikian diharapkan dengan masuknya bisnis online akan mempengaruhi perilaku masyarakat dimana dalam bertransaksi jual beli yang biasanya secara offline berubah menjadi secara online.
Perkembangan teknologi informasi telah memperlihatkan bahwa internet telah menjadi alat pemasaran yang hebat. Dengan adanya internet, kini banyak toko yang sudah menggunakan media internet sebagai sarana pemasaran. Baik dengan media sosial seperti Faceboook, Twitter, dan Instagram maupun menggunakan media marketplace seperti Shopee, Bukalapak, dan Tokopedia.

Dengan masuknya marketplace di Indonesia dengan kemudahan kemudahan yang ditawarkan, pengguna media marketplace di Indonesia semakin meningkat. Hal ini dapat dilihat pada diagram berikut: 
Jumlah kunjungan marketplace di Indonesia
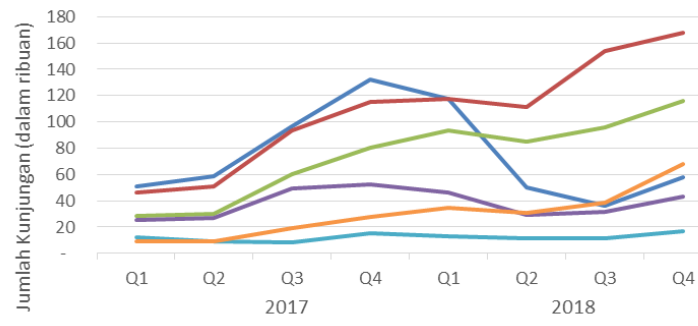

Gambar 1. Perkembangan Jumlah Kunjungan Marketplace di Indonesia

Sumber: Data Primer, 2019, diolah dari iPrice

Dilihat dari tabel jumlah kunjungan marketplace di Indonesia diatas terlihat bahwa jumlah kunjungan marketplace setiap per kuartal relatif semakin meningkat. Karena semakin meningkatnya kunjungan marketplace, maka akan semakin meningkat pula transaksi yang dilakukan pada marketplace tersebut.

Selain itu orang tidak akan langsung percaya begitu saja terhadap toko toko di dalam marketplace. Setiap orang memiliki ketakutan ketika melakukan pembelian melalui internet. Masing masing konsumen memiliki pendapat yang berbeda dalam memilih toko yang terpercaya dalam berbelanja di toko online. Konsumen akan menggali berbagai petunjuk dari toko tersebut untuk meyakinkan bahwa toko tersebut dapat dipercaya. Tanpa adanya rasa kepercayaan dari konsumen, mereka tidak akan memberikan data pribadi mereka maupun melakukan transaksi dengan toko tersebut. (Bauman, 2015). Selain itu, didalam marketplace konsumen juga tidak dapat menyentuh langsung produk yang akan dibelinya (Rathee \& Rajain, 2019). Oleh karena itu, perlu adanya upaya dalam membangun customer trust agar pembeli percaya dan timbul minat dalam bertransaksi dengan toko tersebut.

Walaupun tidak dapat menyentuh secara langsung, dengan menjaga interaksi, komunikasi, dukungan, empati, dan respons yang baik antar penjual dan pembeli akan menciptakan hubungan yang berkelanjutan (Kousheshi et al, 2019). Dengan demikian akan mengurangi rasa cemas yang dihadapi konsumen sehingga akan meningkatkan intensi pembelian konsumen.

Dalam menumbuhkan intensi pembelian dalam marketplace, ada beberapa faktor customer trust yang perlu dibangun dalam menjalankan bisnis secara online. Dalam membangun kepercayaan konsumen, dapat dimulai dengam membangun aspek ability, benevolence of business dan integrity toko, karena dengan membangun kepercayaan konsumen, tidak hanya akan meningkatkan intensi pembelian, namun juga akan mengurangi resiko dan secara tidak langsung akan meningkatkan loyalitas pelanggan (Zhang \& Li, 2019). Oleh karena itu, dalam upaya membangun cutomer trust yang baik, perlu adanya upaya dalam meningkatkan ability, benevolence of business dan integrity pada toko online.

Semakin tingginya minat masyarakat dalam memakai teknologi online dalam bertransaksi jual beli, membuat banyak pemilik toko maupun perseorangan yang mulai mengembangkan usahanya di dalam media marketplace. Salah satu toko tersebut adalah toko "SoWellShop" yang didirikan oleh Sdr. Weliyan Tanoyo sejak 20 Agustus 2011 yang memulai usahanya dengan berjualan alat alat kesehatan dan toko herbal yang dipasarkan melalui media internet baik Facebook, Shopee, Tokopedia, Bukalapak, dan lain-lain. Hal yang sangat sulit dalam menjalankan usaha online adalah dalam meyakinkan konsumen mengenai keaslian produk dan keaslian tokonya sehingga akan berdampak terhadap minat konsumen dalam bertransaksi dengan toko tersebut. Hal ini tidaklah mudah, mengingat membangun customer trust di dalam marketplace merupakan hal yang sulit untuk dilakukan.

Dari beberapa uraian diatas, penulis berusaha mencari seberapa besar pengaruh ability, benevolence of business, dan integrity dalam membangun customer trust dan seberapa besar pengaruhnya dalam meningkatkan intensi pembelian pada toko SoWellShop. 


\section{E-Commerce}

Perkembangan e commerce tak lepas dari adanya internet. Dengan adanya internet dapat dijadikan sebagai sarana distribusi yang kuat, sehingga saat ini bermunculan berbagai e-commerce dengan platform yang mendukung sarana distribusi dalam memunculkan peluang peluang dalam mengembangkan usahaannya (Sahi et al, 2016). Saat ini banyak perusahaan maupun perorangan yang membangun e-commerce untuk memasarkan maupun meyakinkan konsumen terhadap produk yang dipasarkan. karena dengan membuat e-commerce akan dapat mempermudah komunikasi didalam sistem online, mitra bisnis, dan pelanggan dengan biaya yang efektif (Sharma \& Lijuan 2015).

\section{Marketplace}

Pengaruh bisnis melalui media online sangat besar sehingga memungkinkan untuk merubah pola masyarakat untuk loyal terhadap penyedia jasa transaksi digital seperti marketplace. Karena dengan adanya marketplace akan menjembatani jutaan pembeli dan penjual secara bersamaan (Hänninen et al, 2018). Jadi, dapat dikatakan marketplace adalah perantara antara pengguna dengan vendor (pemilik produk). Peran marketplace sangat besar bagi pemilik toko/perusahaan karena dengan adanya marketplace akan semakin memudahkan perusahaan dalam hal menekan biaya pengiriman, menambah konsumen baru, komunikasi dengan konsumen. Dengan demikian dengan adanya marketplace, hubungan dengan pelanggan lebih mudah, konsumen dimudahkan dalam bertransaksi, serta pengiriman juga akan lebih cepat (Jung Oh \& Wook Kim, 2011). Hingga saat ini marketplace sangat membantu baik penjual maupun pembeli. Dimana pembeli dimudahkan dalam bertransaksi dan penjual dipermudah dalam memperluas jaringan pemasarannya.

\section{Customer Trust}

Customer trust merupakan hal yang penting di dalam membangun hubungan yang baik antara penjual dan pembeli. Karena disaat bertransaksi di marketplace, konsumen dan penjual tidak bertemu langsung. Oleh karena itu penting dalam membangun kepercayaan terhadap toko karena didalam marketplace masih ditemui berbagai aksi curang penjual yang menjadi alasan konsumen berhati hati dalam memilih toko dalam marketplace (Wei et al, 2019). Dalam membangun kepercayaan dengan konsumen didalam marketplace, ada beberapa faktor yang perlu dibangun dalam menjalankan bisnis secara online. Dalam membangun kepercayaan konsumen, dapat dimulai dengam membangun aspek ability, benevolence of business dan integrity toko, karena dengan adanya faktor faktor tersebut, tidak hanya akan meningkatkan intensi pembelian, namun juga akan mengurangi resiko dan secara tidak langsung akan meningkatkan loyalitas pelanggan (Zhang \& $\mathrm{Li}$, 2019). Oleh karena pentingnya kepercayaan di dalam menjalankan bisnis di marketplace, pemilik toko hendaknya tidak mengabaikan factor-faktor yang dapat mempengaruhi kepercayaan konsumen.

\section{Dimensi Trust}

Menurut Blackey (2016) pada 2007, datanglah Shawn Burke dan tim penelitiannya di: Universitas Florida untuk merangkum 30 tahun debat dan untuk menyimpulkan bahwa semua model customer trust dapat diringkas menjadi tiga pilar umum yaitu: 1) Ability, mengacu pada kompetensi profesional untuk memenuhi tugas inti kepemimpinan eksekutif. Kita bisa bersikap sebaik yang kita inginkan, jujur serta terbuka dan peduli, tetapi jika kita terus mengecewakan dalam hal pengiriman, maka kepercayaan terhadap bisnis kita akan hilang; 2) Benevolence of business, mengacu pada kepedulian kita terhadap kesejahteraan orang lain. Dapat diartikan kita menunjukkan harapan baik kita kepada orang lain melalui perawatan, kemurahan hati dan kebaikan; 3) Integrity, mengacu pada sejauh mana kita "sejalan dengan apa yang kita ucapkan". Kita harus dapat diandalkan dalam perilaku kita dan secara konsisten hidup sesuai dengan 
nilai-nilai dan standar yang telah kita tetapkan untuk diri kita sendiri dan organisasi. Integrity memiliki komponen etis: yaitu menyiratkan kejujuran, keterbukaan, dan bersikap adil.

\section{Purchase Intention}

Tujuan utama penjualan online adalah terciptanya intensi pembelian. Banyak faktor yang mempengaruhi minat konsumen dalam memilih produk dalam penjualan online. Karena didalam belanja online memiliki berbagai resiko, mulai dari resiko keuangan, keamanan, pengiriman, produk yang tidak sesuai, dan sebagainya (Kamalul et al, 2019). Oleh karena itu perlu adanya upaya-upaya dalam mengurangi rasa cemas konsumen mengenai resiko-resiko yang mungkin ditimbulkan dari berbelanja secara online.

Dalam memilih produk online yang akan dibeli, konsumen cenderung melihat karakteristik toko serta membandingkan harga. Karakteristik toko tersebut dapat meyakinkan konsumen mengenai kebenaran toko. Karakteristik dan ulasan akan menjadi bahan pertimbangan konsumen dalam menentukan dimana akan bertransaksi (Chakraborty, 2019). Karakteristik toko yang baik akan semakin menarik konsumen untuk bertransaksi dengan toko tersebut.

\section{Pengaruh Ability Terhadap Customer Trust}

Ability dalam menumbuhkan customer trust dapat dianggap sebagai hal yang wajib di perhatikan. Konsumen akan melihat seberapa handal toko, seberapa manfaat, dan seberapa relevan dan akurat informasi yang didapat. Sehingga akan semakin meyakinkan konsumen untuk bertransaksi terhadap toko tersebut (Maia et $a l$, 2018). Hal ini penting karena dalam marketplace, penjual dan pembeli tidak bertemu langsung. Maka perlu adanya upaya dalam meningkatkan ability dalam menumbuhkan customer trust dalam mengelola marketplace.

Kemampuan toko online dapat terlihat dari keterampilan dan cara menyelesaikan pesanan yang baik.
Konsumen akan menilai kemudahan dan kenyamanan dalam bertransaksi, kemampuan untuk melayani konsumen sangat penting dalam membuat kesepakatan dengan konsumen (Bauman, 2015). Dengan demikian konsumen akan merasa yakin mengenai produk yang akan diambil.

Ability berpengaruh positif terhadap customer trust. Maka dari itu, dengan meningkatkan ability pada toko online, maka akan meningkatkan customer trust terhadap toko tersebut. Semakin tinggi ability, maka customer trust juga akan semakin tinggi (Hsiao et al, 2010). Karena terdapat pengaruh yang positif, maka dalam menjalankan bisnis online, ability menjadi faktor yang perlu diperhatikan karena akan memiliki dampak terhadap customer trust. Atas dasar uraian diatas, maka dapat disajikan hipotesis sebagai berikut:

$\mathrm{H}_{1}$ : Ability berpengaruh positif terhadap customer trust

\section{Pengaruh Benevolence of Business Terhadap Customer Trust}

Benevolence of business didalam toko online dapat diartikan bahwa penjual dan pembeli sama sama memiliki harapan yang baik dalam membangun komitmen bersama. Benevolence didasarkan pada reaksi afektif langsung terhadap daya tarik, dengan komunikasi yang baik dapat memunculkan respons emosional terhadap niat baik dalam menjalin transaksi sehingga akan menunjang rasa percaya terhadap toko tersebut (Brengman \& Karimov, 2012). Menjalin hubungan konsumen yang baik akan memberikan pandangan konsumen bahwa toko memiliki nilai benevolence of business yang tinggi sehingga konsumen yang sebelumnya belum pernah membeli akan tumbuh rasa kepercayaan terhadap toko tersebut.

Membangun bisnis dengan membangun benevolence of business tidaklah mudah. Membangun benevolence yang baik dapat diartikan penjual akan mempertimbangkan dan bertindak yang terbaik untuk kepentingan pembeli. Hal ini akan beresiko karena penjual dituntut lebih 
dari yang seharusnya dilakukan (B. Murphy, 2003). Namun dengan membangun benevolence yang baik dapat meningkatkan rasa percaya dan loyal konsumen terhadap toko. Dengan mencari konsumen yang loyal akan lebih menguntungkan toko dalam jangka panjang.

Benevolence of business berpengaruh positif terhadap customer trust. Maka dari itu, dengan meningkatkan benevolence of business pada toko online, maka akan meningkatkan customer trust terhadap toko tersebut. Semakin tinggi benevolence of business, maka customer trust juga akan semakin tinggi (Hsiao et al, 2010). Karena benevolence of business memiliki pengaruh yang positif dan berdampak dalam jangka panjang, maka dalam upaya meningkatkan customer trust di dalam bisnis online, benevolence of busines juga menjadi salah satu faktor yang harus diperhatikan oleh penjual dalam membangun usahanya di bidang online. Berdasar uraian diatas, maka dapat disajikan hipotesis sebagai berikut:

$\mathrm{H}_{2}$ : Benevolence of business berpengaruh positif terhadap customer trust

\section{Pengaruh Integrity Terhadap Customer Trust}

Integritas di dalam marketplace, dapat diartikan toko online dapat menunjukkan kebiasaan toko online dalam membangun konsistensi terhadap apa yang diberikan terhadap konsumen. Integritas dapat dilihat dari cara penjual dalam memberikan syarat dan ketentuan yang jelas dalam bertransaksi, maupun cara dalam memberikan jaminan bahwa hak-hak konsumen akan senantiasa dilindungi. (Connolly \& Bannister, 2008). Dengan demikian akan memumbuhkan rasa kepercayaan terhadap penjual.

Integritas dapat disebut juga perwujudan komitmen dalam bertransaksi sesuai dengan kesepakatan yang telah dibuat. Dalam membangun integritas yang baik dapat dilakukan dengan selalu memberikan solusi untuk setiap masalah yang berkaitan langsung dengan konsumen. Selain itu untuk menunjukkan integritas yang baik dapat dilakukan dengan menjaga nama baik toko maupun reputasi toko (Rampl et al, 2012). Dengan demikian diharapkan dengan membangun integritas yang baik akan meningkatkan rasa kepercayaan konsumen terhadap toko.

Dengan integritas yang baik akan mendorong pola pemikiran yang rasional dan cermat untuk memotivasi konsumen dalam meningkatkan rasa kepercayaan. Integritas sendiri dapat dilihat dari kejujuran, keadilan, kredibilitas, dan keandalan dalam membangun hubungan dengan konsumen (Brengman \& Karimov, 2012). Semakin besar peran penjual dalam berusaha membangun integritas yang baik, pembeli akan semakin percaya dengan toko tersebut. Hal ini dikarenakan pembeli biasanya akan lebih percaya terhadap toko yang memiliki komitmen dalam menjalankan bisnisnya. Sehingga, konsumen akan lebih yakin untuk membelanjakan dananya pada toko tersebut

Integrity berpengaruh positif terhadap customer trust. Maka dari itu, dengan meningkatkan integrity pada toko online, maka akan meningkatkan customer trust terhadap toko tersebut. Semakin tinggi integrity, maka customer trust juga akan semakin tinggi (Hsiao et al, 2010). Karena integrity memiliki pengaruh yang positif dalam meyakinkan penjual terhadap komitmennya, maka hal ini juga menjadi faktor yang harus diperhatikan dalam membangun usaha dalam toko online. Atas dasar uraian diatas, maka dapat disajikan hipotesis sebagai berikut:

$\mathrm{H}_{3}$ : Integrity berpengaruh positif terhadap customer trust

\section{Pengaruh Customer Trust terhadap Purchase Itention}

Kepercayaan dianggap faktor penting dalam membangun minat beli secara online. Jika kepercayaan semakin tinggi maka hal tersebut dapat menumbuhkan intensi pembelian konsumen untuk bertransaksi secara online. Karena tanpa adanya rasa kepercayaan dari konsumen, mereka tidak akan memberikan data pribadi mereka maupun melakukan transaksi dengan toko 
tersebut (Bauman, 2015). Karena didalam berbisnis secara online, kurangnya kepercayaan merupakan alasan utama konsumen tidak melanjutkan transaksi terhadap toko tersebut (Maia et al, 2018). Dalam marketplace, membangun customer trust merupakan hal yang wajib dalam membangun purchase intention. Karena hal utama membangun bisnis online adalah terjadinya transaksi. Tanpa adanya kepercayaan dari pembeli, mustahil akan terjadi transaksi terhadap toko tersebut.

Banyak hal yang menjadi faktor tidak kurangnya minat pelanggan. Dalam menjalankan bisnis online sering ditemui beberapa konsumen yang hanya berminat terhadap suatu produk, namun tidak memiliki kepercayaan untuk melanjutkan transaksi terhadap toko tersebut. Salah satu alasannya dikarenakan konsumen tidak bisa memeriksa barang yang akan dibeli. Oleh karena itu untuk dapat meyakinkan konsumen adalah dengan menjaga reputasi toko dan testimoni pembeli sebelumnya. (B. Murphy, 2003). Dalam transaksi berbasis online, kepercayaan menjadi salah satu penunjang utama konsumen dalam menentukan dalam kelanjutan bertransaksi. Konsumen akan menilai seberapa handal toko, seberapa manfaat, dan seberapa relevan dan akurat informasi yang didapat. Sehingga akan semakin meyakinkan konsumen untuk bertransaksi terhadap toko tersebut (Maia et $a l, 2018)$. Peran penjual dalam meningkatkan kepercayaan tidaklah mudah. Kepercayaan adalah faktor utama yang harus dibentuk agar terciptanya intensi pembelian dalam penjualan online.

Customer Trust berpengaruh positif terhadap purchase intention, dimana meningkatnya customer trust pada toko online, akan meningkatkan purchase intention terhadap toko tersebut. (Pappas, 2018). Oleh karena itu, dengan membangun kepercayaan konsumen, diharapkan akan memunculkan minat dari pelanggan sehingga terjadi transaksi yang diharapkan. Berdasar uraian diatas, maka dapat disajikan hipotesis sebagai berikut:
$\mathrm{H}_{4}$ : Customer trust berpengaruh positif terhadap purchase intention

Dari rangkaian hipotesis diatas maka dapat digambarkan model kerangka pemikiran sebagai berikut:

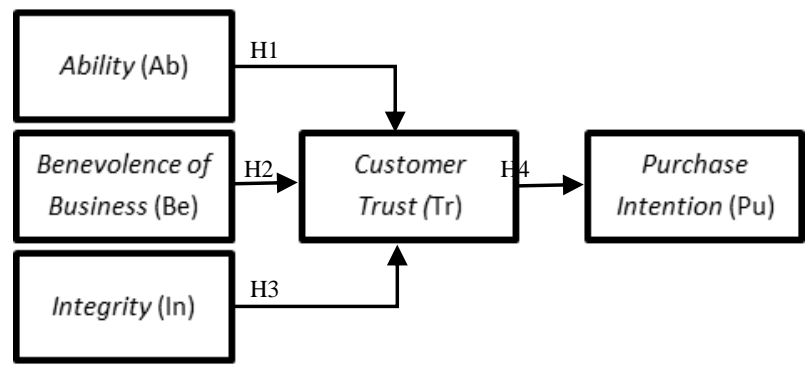

Gambar 2. Model Kerangka Pemikiran Sumber: Data Primer, 2019, diolah dari iPrice

\section{METODE}

Penelitian ini menggunakan pendekatan kuantitatif dengan metode survey untuk mengumpulkan data. Data dikumpulkan dengan menggunakan kuesioner yang dibagikan kepada responden. Penelitian ini mencari hubungan atau pengaruh antar variabel sehingga dapat digolongkan sebagai penelitian asosiatif Sugiono (2018). Variabel yang digunakan dalam penelitian ini terdiri dari lima variabel dengan empat variabel bebas dan dua variabel terikat. Variabel bebas tersebut adalah Ability (Ab), Benevolence of Business (Be), Integrity (In), dan Customer Trust (Tr). Variabel terikatnya adalah Customer trust (Tr) dan Purchase Intention $(\mathrm{Pu})$.

Populasi pada penelitian ini mencakup seluruh masyarakat secara umum yang sudah mengenal jual beli melalui media onlinel marketplace baik yang pernah melakukan pembelian maupun belum. Pengambilan populasi ini mengacu kepada karakteristik masyarakat dalam berbelanja online. Dalam berbelanja dalam marketplace, setelah konsumen mencari dan membandingkan produk, konsumen akan melihat karakteristik toko tersebut. Karakteristik toko tersebut yang meyakinkan konsumen dalam bertransaksi (Sarwono \& Prihantono, 2012). Dalam hal ini konsumen memiliki penilaian terhadap toko walaupun konsumen belum mengenal toko tersebut. 
Oleh karena itu, penelitian ini meneliti karakteristik konsumen dalam memilih toko yang belum dikenalnya sehingga muncul intensi pembelian dalam toko tersebut.

Penentuan sampel penelitian ini Menggunakan teknik purposive sampling yang termasuk dalam metode non probability sampling dengan mengambil sampel atas pertimbangan atau karakteristik tertentu (Sugiyono, 2018). Penelitian ini mengambil sampel 100 orang dengan mengacu kepada buku Suryani (2015) menurut Sekaran (2003), yang menyebutkan sampel yang diambil minimal 10 kali jumlah variabel.

Dalam penelitian ini, data dikumpulkan menggunakan kuesioner. Sebelum responden menjawab kuesioner, terlebih dahulu responden diperkenalkan tentang toko toko SoWellShop melalui deskripsi toko tersebut. Hal ini berdasarkan karakteristik masyarakat dalam berbelanja online dalam memilih toko yang belum dikenalnya lebih melihat karakteristik toko tersebut untuk meyakinkannya dalam bertransaksi. Oleh karena itu, dalam hal ini konsumen diperkenalkan toko yang asing (SoWellShop) di dalam marketplace Tokopedia, Bukalapak, dan Shopee untuk kemudian diberikan pertanyaan mengenai toko tersebut. Hal ini sejalan dengan yang dilakukan Harris \& Goode (2010) dalam meneliti online shop berbasis website dengan memberikan data toko online yang belum dikenal untuk di amati, kemudian diberikan kuesioner untuk diisi. Penelitian lainnya, seperti penelitian Brengman dan Karimov (2012) yang meneliti mengenai website $e$ commerce $B 2 C$ di Belgia juga membagikan kuesioner secara acak melalui media facebook.

Pada penelitian ini menggunakan data primer dan sekunder. Data primer diperoleh secara langsung dari jawaban kuesioner yang dibagikan kepada masyarakat yang sudah mengenal belanja secara online. Sedangkan data sekunder diambil dari profil SoWellShop, data penjualan yang diambil dari aplikasi penjualan di Shopee, Bukalapak, dan Tokopedia dalam kurun waktu tertentu dan data kunjungan marketplace dari iPrice selama periode tertentu. Penelitian ini menggunakan kuesioner yang berisi pertanyaan/pernyataan tentang variabel penelitian, yang telah dipersiapkan lebih dahulu. Kuesioner yang diberikan bersifat tertutup dimana setiap pertanyaan/pernyataan telah disediakan pilihan jawaban menurut skala Likert, sehingga responden tinggal memilih jawaban yang mereka anggap sesuai. (Sugiyono, 2018).

Sebelum digunakan untuk penelitian, sebelunya dilakukan pengujian validitas dan reliabilitas terlebih dahulu. Hal ini dilakukan untuk mendapatkan data yang valid dan reliabel. Dalam analisa hipotesis, penelitian ini menggunakan analisa regresi berganda dan analisa regresi sederhana. Analisis regresi digunakan peneliti untuk meramalkan dan melihat pengaruh antar variabel yang diteliti (Sugiyono, 2018) Analisis regresi berganda digunakan untuk melihat apakah terdapat pengaruh Ability, Benevolence of Business, dan Intregrity terhadap Customer Trust dan analisa regresi sederhana digunakan untuk mengetahui pengaruh Customer Trust terhadap Purchase Intention. Sehingga didapatkan persamaan regresinya:

$$
\begin{gathered}
\operatorname{Tr}=\beta 1 \mathrm{Ab}+\beta 2 \mathrm{Be}+\beta 3 \mathrm{In} \\
\mathrm{Pu}=\beta 4 \mathrm{Tr}
\end{gathered}
$$

Setelah didapatkan rumus regresinya, peneliti melihat kebenaran hipotesis menggunakan uji $\mathrm{T}$. Uji T dianalisa dengan membandingkan nilai signifikasnsi yang dihitung dengan nilai signifikansi yang telah ditetapkan. Jika signifikansi $\mathrm{T}_{\text {hitung }}$ lebih kecil dari $\alpha$ maka artinya variabel independen berpengaruh secara parsial terhadap variabel dependen.

Uji yang terakhir adalah uji koefisien determinasi. Uji ini digunakan peneliti dalam melihat seberapa jauh model yang didapat peneliti dalam menerangkan variasi variabel dependen. Uji ini akan memprediksi seberapa besar variabel variabel bebas yang diambil peneliti dapat menerangkan variabel terikat. Jika nilai yang didapatkan mendekati 1, maka variable-variabel bebas yang diambil peneliti 
dapat memberikan semua informasi dalam memprediksi variabel terikat.

\section{HASIL DAN PEMBAHASAN}

Sebelumya data diuji validitas dan reliabilitasnya dengan hasil uji validitas semua data memiliki nilai $r_{\text {hitung }}>r_{\text {tabel }}$, dan uji reliabilitas diperoleh nilai cronbach's alfa $>0,700$ sehingga dapat simpulkan data yang diambil valid dan reliabel. Tahap selanjutnya akan dilakukan uji hipotesis. Pengujian hipotesis dilakukan untuk mengetahui pengaruh membangun kepercayaan konsumen untuk meningkatkan intensi pembelian. Dalam penelitian ini digunakan analisa regresi berganda dan analisa regresi sederhana. Berikut ini hasil analisis regresi dengan program SPSS.

Tabel 1. Analisis Regresi Berganda Pengaruh Ability Benevolence of Business dan Integrity terhadap Customer Trust

\begin{tabular}{lllll}
\hline \multicolumn{1}{c}{ Variabel } & $\begin{array}{c}\text { Koef } \\
\text { Reg. }\end{array}$ & t-hit & Sig. & Kesimp \\
\hline Ability & 0,422 & 4,236 & 0,000 & Signifikan \\
Benevolence & 0,277 & 2,618 & 0,010 & Signifikan \\
Integrity & 0,210 & 2,345 & 0,021 & Signifikan \\
\hline Konstanta & $=-0,381$ & & \\
R square & $=0,710$ & & \\
F hitung & $=78,187$ & & \\
Sig. & $=0,000$ & & \\
\hline
\end{tabular}

Sumber: data diolah

Berdasarkan hasil pada tabel 1 dapat diketahui nilai koefisien regresi ability $(\mathrm{Ab})$, benevolence of business (Be), dan integrity (In) memiliki hasil koefisien regresi positif. Maka dapat disimpulkan bahwa ability (Ab), benevolence of business $(\mathrm{Be})$, dan integrity (In) memiliki pengaruh secara positif terhadap terhadap customer trust (Tr). Dari data tersebut, maka dapat disimpulkjan untuk hasil persamaan regresi adalah sebagai berikut:

$$
\operatorname{Tr}=0,422 \mathrm{Ab}+0,277 \mathrm{Be}+0,21 \mathrm{In}
$$

Tabel 2. Analisis Regresi Sederhana Pengaruh Customer Trust Terhadap Purchase Intention

\begin{tabular}{lllll}
\hline \multicolumn{1}{c}{ Variabel } & $\begin{array}{l}\text { Koef } \\
\text { Reg. }\end{array}$ & t-hit & Sig. & Kesimp \\
\hline Cust Trust & 0,635 & 8,541 & 0,000 & Signifikan \\
\hline Konstanta & $=3,195$ & & \\
R square & $=0,427$ & & \\
F hitung & $=72,950$ & & \\
Sig. & $=0,000$ & & \\
\hline
\end{tabular}

Sumber: data diolah

Berdasarkan hasil dari tabel 2 dapat diketahui bahwa koefisien regresi customer trust (Tr) memiliki koefisien regresi positif sehingga dapat disimpulkan bahwa customer Trust (Tr) memiliki pengaruh secara positif terhadap terhadap purchase intention $(\mathrm{Pu})$. Dari data diatas, maka hasil persamaan regresinya sebagai berikut:

$$
\mathrm{Pu}=0,635 \mathrm{Tr}
$$

Selanjutnya akan dilakukan uji $\mathrm{t}$ untuk melihat pengaruh secara parsial antar variabel. Dari tabel 1 nilai signifikansi dari ability sebesar 0,000; benevolence of business sebesar 0,010; integrity sebesar 0,021; dan customer trust sebesar 0,000, yang berarti semua nilai signifikansi lebih kecil dari $0,05(\operatorname{sig}<0,05)$. Sehingga dapat diambil kesimpulan semua variabel tersebut secara parsial berpengaruh secara signifikan terhadap variabel terikat.

Selanjutnya akan dicari besarnya pengaruh variabel bebas dengan variabel terikat . Hasil uji R2 pada variable ability, benevolence of business, dan integrity terhadap customer trust, didapatkan nilai $\mathrm{R}$ square sebesar 0,710 sehingga dapat disimpulkan bahwa customer trust dipengaruhi variabel ability, benevolence of business, dan integrity sebesar 71,0\%, sedangkan $29,0 \%$ dipengaruhi oleh faktor lainnya. Sedangkan untuk hasil uji R2 pada variable customer trust terhadap purchase intention, didapatkan hasil $\mathrm{R}$ square sebesar 0,427 sehingga dapat diambil kesimpulan bahwa purchase intention dipengaruhi variable customer trust sebesar 42,7\%, sedangkan $57,3 \%$ dipengaruhi oleh faktor lainnya. 


\section{Pembahasan}

Pengaruh Ability Terhadap Customer Trust

Dari hasil penelitian yang dilakukan didapatkan variabel ability berpengaruh positif terhadap customer trust. Hal ini berdasarkan hasil signifikansi variabel ability lebih kecil dari 0,05 $(0,000<0,05)$, dan didapatkan nilai $\mathrm{R}$ square positif sebesar 0,422 yang berarti setiap penambahan nilai ability sebesar 1, maka akan menambah nilai customer trust sebesar 0,422. Selanjutnya ditemukan nilai dari koefisien regresi ability bernilai positif yang berarti jika ability meningkat, maka customer trust juga akan meningkat. Maka dari hasil penelitian hipotesis pertama yang menyatakan "Ability berpengaruh positif terhadap customer trust" diterima.

Beberapa penelitian mendapatkan hasil yang sama. Seperti penelitian yang dilakukan oleh Rampl et al (2012) terhadap pengecer makanan di Jerman, Touray et al (2015) terhadap pengguna layanan internet provider di Kenya, begitu juga dengan penelitian yang dilakukan oleh Hsiao et al (2010) yang meneliti mengenai website game. Penelitian-penelitian tersebut menunjukkan bahwa ability berpengaruh positif terhadap kepercayaan. Sehingga, dapat disimpulkan ability juga berpengaruh penting didalam membangun kepercayaan dalam pengecer makanan dan kepercayaan terhadap layanan internet provider.

\section{Pengaruh Benevolence of Business Terhadap Customer Trust}

Dari hasil penelitian yang dilakukan didapatkan variabel benevolence of business berpengaruh positif terhadap customer trust. Hal ini berdasarkan hasil signifikansi variabel benevolence of business lebih kecil dari $0,05(0,000<0,05)$, dan didapatkan nilai $\mathrm{R}$ square positif sebesar 0,277 yang berarti setiap penambahan nilai benevolence of business sebesar 1, maka akan menambah nilai customer trust sebesar 0,277. Selanjutnya ditemukan nilai dari koefisien regresi benevolence of business bernilai positif yang berarti jika benevolence of business meningkat, maka customer trust juga akan meningkat. Maka dari hasil penelitian hipotesis kedua yang menyatakan "Benevolence of business berpengaruh positif terhadap customer trust" diterima

Penelitian yang lain juga menunjukkan hal yang sama. Seperti penelitian yang dilakukan oleh Touray et al (2015) terhadap pengguna layanan internet provider di Kenya dan penelitian Hsiao et al (2010) mengenai website game. Penelitian tersebut menunjukkan bahwa benevolence of business berpengaruh positif terhadap kepercayaan. Sehingga, dapat disimpulkan benevolence of business juga berpengaruh penting didalam membangun kepercayaan dalam media sosial dan layanan internet provider.

Namun, penelitian lain menemukan hasil yang berbeda. Seperti yang diteliti oleh Rampl et al (2012) terhadap pengecer makanan di Jerman. Hasil menunjukkan benevolence of business tidak berpengaruh terhadap kepercayaan. Dalam temuannya diungkapkan benevolence of business adalah sifat yang jauh lebih pribadi, dan tidak mudah diterapkan pada pengecer makanan yang lebih sering terlihat menekan pelanggan dibandingkan dengan toko skala kecil seperti tukang daging atau toko kelontong. Namun, hal ini kemungkinan juga bisa berbeda hasil jika diteliti di Indonesia. Karena terdapat kemungkinan perbedaan sifat seseorang. Hal ini tentu saja berpengaruh terhadap benevolence of business mengingat benevolence of business sangat dipengaruhi sifat dari orang tersebut..

\section{Pengaruh Integrity Terhadap Customer Trust}

Dari hasil penelitian yang dilakukan didapatkan variabel integrity berpengaruh positif terhadap customer trust. Hal ini berdasarkan hasil signifikansi variabel integrity lebih kecil dari $0,05(0,021<0,05)$, dan didapatkan nilai $\mathrm{R}$ square positif sebesar 0,210 yang berarti setiap penambahan nilai integrity sebesar 1, maka akan menambah nilai customer trust sebesar 0,21 . Selanjutnya ditemukan nilai dari koefisien regresi integrity bernilai positif yang berarti jika 
integrity meningkat, maka customer trust juga akan meningkat. Maka dari hasil penelitian hipotesis ketiga yang menyatakan "Integrity berpengaruh positif terhadap customer trust" diterima.

Penelitian yang lain juga menunjukkan hal yang sama. Seperti penelitian yang dilakukan Hsiao et al (2010) mengenai website game dan Rampl et al (2012) terhadap pengecer makanan di Jerman. Kedua penelitian tersebut menunjukkan bahwa integrity berpengaruh positif terhadap kepercayaan. Sehingga, dapat disimpulkan integrity juga berpengaruh penting di dalam membangun kepercayaan dalam media sosial dan pengecer makanan. Berbeda hasil dengan benevolence of business, penelitian Rampl et al (2012) terhadap integrity memiliki pengaruh yang positif. Hal ini dikarenakan pengecer makanan akan lebih dipercaya jika memiliki komitmen dalam dirinya.

Namun, penelitian lain menemukan hasil yang berbeda. Seperti yang diteliti oleh Touray et al (2015) terhadap pengguna layanan internet provider di Kenya. Hasil menunjukkan integrity tidak berpengaruh terhadap kepercayaan. Dalam temuannya melalui survei dan wawancara menunjukkan ketidakpercayaan yang tinggi pada masyarakat Kenya. Masyarakat lebih banyak mengembangkan potensi jalannya dengan caranya sendiri untuk tujuan mereka bersama. Dengan kata lain, ada faktor ketidak-percayaan di Kenya dalam membuat tingkat kepercayaan rendah.

\section{Pengaruh Customer Trust terhadap Purchase Itention}

Dari hasil penelitian yang dilakukan didapatkan variabel customer trust berpengaruh positif terhadap purchase intention. Hal ini berdasarkan hasil signifikansi variabel customer trust lebih kecil dari $0,05(0,000<0,05)$, dan didapatkan nilai $\mathrm{R}$ siquare positif sebesar 0,635 yang berarti setiap penambahan nilai customer trust sebesar 1, maka akan menambah nilai purchase intention sebesar 0,21 . Selanjutnya ditemukan nilai dari koefisien regresi customer trust bernilai positif yang berarti jika customer trust meningkat, maka purchase intention juga akan meningkat. Maka dari hasil penelitian hipotesis keempat yang menyatakan "Customer trust berpengaruh positif terhadap Purchase Intention" diterima.

Dalam temuannya, Pappas (2018) menungkapkan bahwa didalam berbelanja online, kepercayaan, kebahagiaan, dan pengalaman pelanggan adalah alasan utama konsumen dalam meneruskan pembeliannya secara online, sedangkan layanan yang buruk dan pengalaman produk, yang akan mengarah konsumen untuk tidak melanjutkan transaksinya.

Hasil yang sama juga ditemukan pada penelitian Sahi et al (2016) yang berjudul "Role of trusting beliefs in predicting purchase intentions" meneliti mengenai sistem berbelanja online di India dengan mengambil sampel mahasiswa di India. Hasil dari penelitian tersebut didapatkan bahwa kepercayaan konsumen berpengaruh positif dan signifikan terhadap intensi pembelian dalam berbelanja online mahasiswa di India. Begitu juga dengan penelitian Kaur \& Khanam (2015) mengenai online shopping di Korea juga mengungkapkan bahwa memang kepercayaan konsumen mempengaruhi intensi pembelian dalam berbelanja melalui media online.

Customer trust memang menjadi faktor utama dalam mempengaruhi purchase intention konsumen. Banyak penelitian lain yang menunjukkan hasil yang sama. Seperti penelitian Harris dan Goode (2010) yang meneliti pada online shop berbasis website dan penelitian Brengman dan Karimov (2012) yang meneliti mengenai website $e$ commerce B2C di Belgia. Kedua penelitian tersebut juga mendapatkan hasil yang sama. Yaitu terdapat hubungan yang positif customer trust terhadap purchase intention. Memang di dalam membangun minat beli terutama pada bisnis online perlu dilandasi kepercayaan. Hal ini dikarenakan tidak bertemunya penjual dan pembeli. Oleh karena itu dalam bisnis online, baik marketplace maupun website membangun 
kepercayaan dalam menumbuhkan intensi pembelian merupakan suatu hal yang wajib dilakukan.

\section{Kesimpulan}

Berdasar hasil analisa data dapat disimpulkan: 1) Ability mempunyai pengaruh signifikan positif terhadap customer trust pada toko online SoWellShop, 2) Benevolence of business mempunyai pengaruh signifikan positif terhadap customer trust pada toko online SoWellShop, 3) Integrity mempunyai pengaruh signifikan positif terhadap customer trust pada toko online SoWellShop, dan 4) customer trust mempunyai pengaruh signifikan postif terhadap purchase intention pada toko online SoWellShop.

Berdasarkan hasil penelitian untuk semua pengusaha bisnis online perlu membangun ability, benevolence of business dan integrity yang kuat sehingga dapat customer trust dalam bertransaki. Karena jika customer trust tinggi, maka akan meningkatkan purchase intention.

\section{DAFTAR PUSTAKA}

B. Murphy, G. (2003). Propensity to Trust, Purchase Experience, and Trusting Beliefs of Unfamiliar E-Commerce Ventures. New England Journal of Entrepreneurship, 6(2), 53-64.

Bauman, A. (2015), The Use of The Repertory Grid Technique in Online Trust Research. Qualitative Market Research, 18(3), 362-382

Blackey, J. (2016). The Trusted Executive. United Kingdom: Kogan Page Limited

Brengman, M., \& Karimov, F.P. (2012). The Effect of Web Communities on Consumers' Initial Trust In B2C ECommerce Websites. Journals of Management Research Review, 35(9), 791-817

Chakraborty, U. (2019). The Impact of Source Credible Online Reviews on Purchase Intention. Journal of Research In Interactive Marketing, 13(2), 142-161.+
Connolly, R., \& Bannister, F. (2008). Factors Influencing Irish Consumers' Trust in Internet Shopping. Management Research News, 31(5), 339-358.

Hänninen, M., Smedlund, A., \& Mitronen, L. (2018). Digitalization in Retailing: Multi-Sided Platforms As Drivers of Industry Transformation. Baltic Journal of Management, 13(2), 152168

Harris, L.C., Goode, M.M.H. (2010). Online Servicescapes, Trust, and Purchase Intentions. Journal of Services Marketing, 24(3), 230-243

Hsiao, K., Chuan-Chuan Lin, J., Wang, X., Lu, H., \& Yu, H. (2010). Antecedents and Consequences of Trust in Online Product Recommendations. Online Information Review, 34(6), 935-953

Jung Oh, S., \& Wook Kim, S. (2011). The Effect of B2B E-Marketplace Type on Buyer-Supplier Relational Advantages of E-Marketplace and Firm Performance. Asian Journal on Quality, 12(2), 189-203

Kamalul Ariffin, S., Mohan, T., \& Goh, Y. (2018). Influence of Consumers' Perceived Risk on Consumers' Online Purchase Intention. Journal of Research In Interactive Marketing, 12(3), 309-327

Kaur, G., \& Khanam Quareshi, T. (2015). Factors Obstructing Intentions To Trust and Purchase Products Online. Asia Pacific Journal of Marketing and Logistics27(5), 758-783

Kousheshi, M., Aali, S., Bafandeh Zendeh, A., \& Iranzadeh, S. (2019). The Antecedents and Consequences of Online Relationship Quality in Internet Purchases. Journal of Islamic Marketing

Maia, C., Lunardi, G., Longaray, A., \& Munhoz, P. (2018). Factors and Characteristics that Influence Consumers' Participation in Social Commerce. Revista De Gestão, 25(2), 194-211 
Peta

E-Commerce Https://Iprice.Co.Id/Insights/Mapofeco mmercel. Diakses 15 April 2019

Rampl, L.V., Eberhardt, T., Schu'Tte, R., Kenning, P. (2012). Consumer Trust in Food Retailers: Conceptual Framework and Empirical Evidence. International. Journal of Retail \& Distribution Management, 40(4), 254-272

Rathee, R., \& Rajain, P. (2019), Online Shopping Environments and Consumer's Need for Touch. Journal of Advances in Management Research

Sahi, G., Sekhon, H., \& Quareshi, T. (2016). Role Of Trusting Beliefs In Predicting Purchase Intentions. International Journal Of Retail \& Distribution Management, 44(8), 860-880

Sarwono, J., \& Prihantono, K. (2012). Perdagangan Online: Cara Bisnis Di Internet. Jakarta: PT Elex Media Komputindo

Sharma, G., \& Lijuan, W. (2015). The Effects Of Online Service Quality of ECommerce Websites On User Satisfaction. The Electronic Library, 33(3), 468-485

Sugiyono. (2018). Metode Penelitian Kuantitatif. Bandung: Alfabeta

Suryani, \& Hendryadi. (2015). Metode Riset Kuantitatif: Teori Dan Aplikasi. Jakarta: Prenadamedia Group

Touray, A., Savolainen, T., Salminen, A., Sutinen, E., \& Dai, Y. (2015). The Role of Trust in Enhancing Internet Use in A High-Risk Society. Journal of Systems and Information Technology, 17(2), 141-166

Udayana, I. B. N., Farida, N., \& Ardyan, E. (2019). Selling Relationship Quality to Increase Salesperson Performance in The Pharmacy Industry, International Journal of Services and Operations Management (IJSOM), 33 (2) 262 285.

Wei, K., Li, Y., Zha, Y., \& Ma, J. (2019). Trust, Risk and Transaction Intention in Consumer-to-Consumer EMarketplaces. Industrial Management \& Data Systems, 119(2), 331-350
Zhang, C., \& Li, Y. (2019). How Social Media Usage Influences B2B Customer Loyalty: Roles of Trust and Purchase Risk. Journal of Business \& Industrial Marketing 